\title{
Effect of Chicken Bone Extract Powder on Epididymal Sperm Quality of Male Wistar Rats
}

\author{
Buranaamnuay $\mathrm{K}^{1^{*}}$, Kettawan $\mathrm{A}^{2}$, Changsangfa $\mathrm{C}^{3}$, Aiemongkot $\mathrm{S}^{3}$ \\ ${ }^{1}$ Molecular Agricultural Biosciences Cluster, Institute of Molecular Biosciences (MB), Mahidol University, Nakhon Pathom 73170, Thailand. \\ ${ }^{2}$ Food Cluster, Institute of Nutrition, Mahidol University, Nakhon Pathom 73170, Thailand. \\ ${ }^{3}$ Institute of Molecular Biosciences (MB), Mahidol University, Nakhon Pathom 73170, Thailand. \\ *E-mail: ningkakanang@yahoo.com
}

(received 07-04-2021; revised 10-05-2021; accepted 15-05-2021)

\begin{abstract}
ABSTRAK
Buranaamnuay K, Kettawan A, Changsangfa C, Aiemongkot S. 2021. Pengaruh tepung ekstrak tulang ayam terhadap kualitas sperma epididimal tikus Wistar jantan. JITV 26(2):74-81. DOI: http://dx.doi.org/10/14334/jitv.v26i2.2729.

Kalsium merupakan salah satu mineral esensial untuk fungsi reproduksi jantan. Kekurangan kalsium mempengaruhi spermatogenesis, fungsi normal sperma dan infertilitas. Pengukuran kualitas sperma tikus yang diberi pakan standar yang mengandung tepung tulang ayam (BEP) dilakukan dalam penelitian ini. Sebanyak dua puluh ekor tikus Wistar jantan berumur 8 minggu ditimbang secara acak dan dibagikan ke dalam dua kelompok yang masing-masing terdiri dari 10 ekor tikus. Pakan yang diberikan secara ad libitum merupakan pakan standar yang mengandung kalsium karbonat (CaCO3, kontrol) atau BEP sebanyak 0,5\% kalsium dalam keduanya. Pada akhir konsumsi pakan selama 8 minggu, pertambahan bobot badan pada kelompok kontrol $(101,33 \pm 21,81 \mathrm{~g})$ tidak berbeda secara nyata $(\mathrm{P}>0,05)$ dibandingkan kelompok BEP $(100,74 \pm 26,80 \mathrm{~g})$. Kualitas sperma in vitro dalam hal konsentrasi, motilitas, viabilitas, resistensi terhadap stress hipotonik, kemampuan reaksi akrosomal dan morfologi dapat dibandingkan antara kelompok control dan BEP (P>0,05). Hasil penelitian menunjukkan bahwa BEP yang ditambahkan dalam pakan merupakan sebuah alternative sumber kalsium yang efektif dan murah sebagai $\mathrm{CaCO} 3$ - kalsium komersial (fortifikan). Setidaknya, tidak memiliki efek merugikan pada fungsi reproduksi jantan.
\end{abstract}

Key Words: Kalsium, Tulang ayam, pakan, Tikus, Sperma

\section{ABSTRACT}

Buranaamnuay K, Kettawan A, Changsangfa C, Aiemongkot S. 2021. Effect of chicken bone extract powder on epididymal sperm quality of male Wistar rats. JITV 26(2): 74-81. DOI: http://dx.doi.org/10/14334/jitv.v26i2.2729.

Calcium is one of the minerals that are essential for male reproductive function. Calcium deficiency adversely affects spermatogenesis, normal sperm function and results in infertility. The sperm quality of rats fed a standard diet containing chicken bone extract powder (BEP) was assessed in the present study. Twenty male 8-week-old rats, Wistar strain, were randomized by weight into two groups of ten rats each and fed ad libitum a standard diet containing calcium carbonate $\left(\mathrm{CaCO}_{3}\right.$, control $)$ or chicken BEP; both were equivalent to $0.5 \%$ calcium. At the end of the 7 -week consumption, the net body weight gains measured in control $(101.33 \pm 21.81 \mathrm{~g})$ and chicken BEP groups $(100.74 \pm 26.80 \mathrm{~g})$ were not significantly different $(\mathrm{P}>0.05)$. The in vitro sperm quality in terms of concentration, motility, viability, resistance to hypotonic stress, acrosomal reaction ability and morphology was comparable between control and chicken BEP (all were $\mathrm{P}>0.05$ ). The results suggest that chicken BEP addition into feeds is an alternative calcium source that is as effective but less expensive as $\mathrm{CaCO}_{3}$, a commercial calcium (fortificant). At least, it has no detrimental effect on male reproductive function.

Key Words: Calcium, Chicken bone, Diet, Rat, Sperm

\section{INTRODUCTION}

Calcium is one of the minerals essential for the biochemical and physiological processes of life (Veldurthy et al. 2016). Apart from a structural component of bone and teeth when combined with phosphorus, calcium plays a vital role in blood coagulation, muscle contraction, hormone and enzyme secretions, the transmission of nerve impulses, and reproductive function in both males and females (Sittikulwitit et al. 2004; Stewart \& Davis 2019). For male reproduction, calcium is necessary for stimulation of sex steroid hormone (i.e., testosterone) production, sperm formation and development, sperm motility, capacitation, acrosome reaction, and fertilization processes (Chung et al. 2011; Valsa et al. 2015). Calcium 
deficiency can be associated with depletion of testosterone, inhibition of spermatogenesis, and subsequently, male infertility (Harchegani et al. 2019).

As the body cannot synthesize calcium, it is important to get enough calcium from dietary intake. Calcium-rich diet sources that are well-known and commonly consumed include dairy products (such as milk, yogurt, and cheese), grains, and green leafy vegetables. However, the only problem with these calcium sources is that these foods contain some substances, for example, fiber, phytic acid, and oxalic acid that have a strong binding affinity to calcium, inhibiting its absorption (Atmokotomo et al. 2019). Chicken bone, a by-product from the poultry industry, contains high calcium but does not contain substances that inhibit calcium absorption. In the year 2002, Kettawan et al. prepared high-quality chicken bone extract powder (BEP) using an inexpensive, effective procedure so-called alkaline treatment. Calcium bioavailability of chicken BEP determined by in vitro dialyzability methods was higher than a traditional calcium-rich diet source and several calcium fortificants. Furthermore, when fortified into shrimp chips, chilipaste, bread, and cookies, chicken BEP was well accepted by consumers; the appearance, taste, and texture of the BEP-fortified products were not significantly different from non-fortified counterparts (Kettawan et al. 2002; Sittikulwitit et al. 2004). As a result, chicken BEP could be deemed an excellent alternative calcium source cheaper than imported commercial calcium fortificants such as calcium carbonate $\left(\mathrm{CaCO}_{3}\right)$. Nonetheless, gastrointestinal (GI) digestion, absorption, metabolism, tissue distribution, safety, and toxicity of chicken BEP assessed in vivo have been reported on a very limited scale and there is no study in male animals. Therefore, the present study was undertaken to determine the effect of chicken BEP on male fertility by appraising the epididymal sperm characteristics of Wistar rats given a standard rodent diet with and without chicken BEP. The outcome of this preclinical testing will potentially be valuable data for conducting clinical trials on humans in the future.

\section{MATERIALS AND METHODS}

\section{Chemicals}

All reagents used in this study were purchased from Sigma-Aldrich (St. Louis, MO, USA) unless otherwise indicated. The food-grade $\mathrm{CaCO}_{3}$ powder was supplied by Thai Poly Chemicals, Co., Ltd., Thailand.

\section{Preparation of chicken BEP}

Betagro Group, Thailand, kindly provided chicken bone. Preparation of chicken BEP was accomplished by an alkaline treatment method adapted from Kettawan et al. (2002).

\section{Animals \\ Acclimation phase}

Twenty male Wistar rats, 7-week old of age and 250$300 \mathrm{~g}$ body weight, were obtained from Nomura Siam International Co., Ltd. At the Institute of Molecular Biosciences (MB), the rats were housed individually in strict hygienic conventional facilities under standard husbandry conditions, i.e., temperature of $22 \pm 2{ }^{\circ} \mathrm{C}$, relative humidity of $55 \pm 15 \%$, and under controlled $(12: 12 \mathrm{~h})$ light-dark cycle. During the one-week acclimation period, the rats had free access to water and food (standard rodent diet No. 082, C.P. Company, Bangkok, Thailand). All animal experiments were approved by the Animal Care and Use Committee at MB (COA.NO.IMB-ACUC 2020/017).

\section{Experimental phase}

After one-week habituation, all rats were weighted by a 2-digit digital scale, divided into two groups of ten animals each, and were given ad libitum for eight weeks on powdered foods containing calcium from two different sources. The rats assigned to group 1 (control) were given $\mathrm{CaCO}_{3}$ based diet containing $0.5 \%$ calcium (Cashman \& Flynn 1996). The animals in group 2 were offered a standard powder diet containing $0.5 \%$ calcium of chicken BEP. The composition of experimental diets is demonstrated in Table 1. Rats' body weights were measured periodically, on the $1^{\text {st }}, 4^{\text {th }}$, and $8^{\text {th }}$ week of consumption.

\section{Epididymal sperm collection}

The methods of epididymal sperm collection were similar to those described by Asadi et al. (2014) and Omirinde et al. (2019), with some modifications. At the end of week $8^{\text {th }}$, the rats were euthanized by carbon dioxide inhalation. The open castration technique subsequently removed the reproductive organs, i.e., testicles and epididymides. During orchiectomy, the testicles were push up through the incision line at a prescrotal area. The tunica vaginalis and spermatic cord were exposed and then scratched. The testicles and epididymides of each rat was placed in a clean container pre-filled with warmed $\left(37^{\circ} \mathrm{C}\right) 0.9 \%(\mathrm{w} / \mathrm{v})$ 
Table 1. The composition (g/100 g) of experimental diets provided to rats

\begin{tabular}{lcc}
\hline \hline \multirow{2}{*}{ Ingredients } & \multicolumn{2}{c}{ Group } \\
\cline { 2 - 3 } & 1 & 2 \\
\hline Cornstarch & 46.57 & 46.57 \\
Casein & 14 & 14 \\
Soybean oil & 4 & 4 \\
Solka Floc-40 & 5 & 5 \\
Dextrin & 15.50 & 15.50 \\
Granular sugar & 10 & 10 \\
AIN-93 mineral mix & & \\
CaCO, formulation & $3.50(0.5 \%$ calcium $)$ & \\
Chicken BEP formulation & & $3.50(0.5 \%$ calcium $)$ \\
AIN-93 vitamin mix & 1 & 1 \\
L-Cystine & 0.18 & 0.18 \\
Choline bitartrate & 0.25 & 0.25 \\
\hline
\end{tabular}

sodium chloride (GHP, Pathum Thani, Thailand). At the nearby andrology laboratory, the organs were further washed with the same medium. The epididymides were separated from the testicles by using operating scissors and sharp, serrated tip forceps. Only the caudal part of epididymides was transferred to a small glass dish containing $1.5 \mathrm{~mL}$ of phosphate buffer saline $(1 \mathrm{X}, \mathrm{pH}$ 7.4) (Apsalagen, Bangkok, Thailand) and cut into tiny pieces. The dish covered with aluminum foil was placed at $37^{\circ} \mathrm{C}$ for $10-15$ min to wait for sperm release. After that, the sperm-rich fluid (approximately $1 \mathrm{~mL}$ of the upper part) was carefully aspirated, deposited into a microtube, and incubated in a $37^{\circ} \mathrm{C}$ water bath while assessing sperm quality.

\section{Sperm analysis}

\section{Sperm count}

For sperm counting, $5 \mu \mathrm{L}$ of the sperm suspension was diluted with formol saline solution [0.9\% sodium chloride and $0.1 \%$ (v/v) $40 \%$ formaldehyde in distilled water] $(1: 40, \mathrm{v} / \mathrm{v})$. Approximately $10 \mu \mathrm{L}$ of the diluted solution was transferred into a hemocytometer (Hausser Scientific, Horsham, PA, USA) and let to settle for 5 min. Epididymal sperm number was determined by counting the cells in 5 large squares under a light microscope (Helmut Hund GmbH, Wetzlar-Nauborn, Germany) at $400 \times$ magnification. Sperm concentration was then calculated from average of the two values and reported as $\left(\times 10^{6}\right)$ per $\mathrm{mL}$ (Badkoobeh et al. 2013).

\section{Sperm motility}

To assess the percentage of motile sperm, a small aliquot $(10 \mu \mathrm{L})$ of suspension was re-pipetted and placed on a glass slide at $37^{\circ} \mathrm{C}$; then overlaid with a coverslip. Randomly ten fields from each slide ( 2 slides/sample) were observed by an experienced evaluator using a blind technique under a phase-contrast microscope $(200 \times)$ (Nikon, Melville, NY, USA). The percentage of sperm motility was recorded based on the appearance of both progressive motile and non-progressive motile sperm (Jaffar et al. 2021).

\section{Sperm viability}

Viability of sperm was appraised by one step staining technique comprising $0.6 \%(\mathrm{w} / \mathrm{v})$ eosin, $5 \%(\mathrm{w} / \mathrm{v})$ nigrosin and $3 \%(\mathrm{w} / \mathrm{v})$ sodium citrate dihydrate prepared in distilled water (pH 7.0) (Buranaamnuay 2020). Fifty microliters each of sperm suspension and the dye were mixed on a glass slide. An aliquot of the mixture was spread on another slide and dried on a hot plate with $37^{\circ} \mathrm{C}$. An evaluator undertook observation of live (unstained head) and dead (any pink or red coloration) sperm with the aid of a brightfield microscope $(\times 400$ magnification). The percentage of viable sperm was calculated from 200 sperm examined (Iswadi et al. 2012).

\section{Sperm tolerance to hypotonic stress}

The present study evaluated the ability of sperm to withstand osmotic stress by determining percentages of 
membrane-intact sperm after incubation in a 75 $\mathrm{mOsm} / \mathrm{kg}$ hypo-osmotic solution (sodium citrate dihydrate and D-fructose dissolved in distilled water) (Buranaamnuay 2019). Fifty microliters of sperm suspension were diluted in $0.5 \mathrm{~mL}$ of the solution. Samples were incubated for $20 \mathrm{~min}$ at $37^{\circ} \mathrm{C}$ and then analyzed using phase-contrast microscopy $(400 \times)$. With a total of 200 sperm counted, the number of sperm with curled tails (intact membranes) and non-curled tails (damaged membranes) was recorded as percentages.

\section{Acrosomal reaction ability of sperm}

As calcium is necessary for sperm capacitation and acrosome reaction, these physiological processes have been enhanced by adding caffeine in vitro (Harchegani et al. 2019). The present study evaluated the ability of sperm to undergo acrosomal reaction by incubating sperm suspension with $1 \mathrm{mM}$ caffeine prepared in PBS $(1: 2, \mathrm{v} / \mathrm{v})$ at $37^{\circ} \mathrm{C}$ (adapted from Funahashi \& Nagai 2001).

The protocol developed for assessing the acrosomal status included using an acrosome-specific fluorescent dye - fluorescein isothiocyanate-conjugated peanut agglutinin (FITC-PNA; $100 \mu \mathrm{g} / \mathrm{mL}$ ), in conjunction with the supravital staining propidium iodide (PI; $340 \mu \mathrm{M})$. For this assay, $10 \mu \mathrm{L}$ of diluted sperm suspension was smeared on a glass slide and dried. The smeared slide was permeabilized in $95 \%$ ethyl alcohol, dried, and spread with a combination of fluorescence dyes $(10 \mu \mathrm{L})$. After incubating in a dark humid chamber at $4^{\circ} \mathrm{C}$ for $2 \mathrm{~h}$ and rinsing with cold distilled water, at least 200 sperm on the slide were observed for the acrosomal status under fluorescence microscopy $(600 \times)$ (DeltaVision Ultra; Cytiva, USA). Sperm with bright green fluorescence over the entire region of the acrosome was judged as acrosome intact. On the other hand, sperm without this staining pattern, i.e., with bright green fluorescence over some part of acrosome or without green color were deemed as acrosome reacted sperm. The percentages of acrosome reacted sperm at 0 and $2 \mathrm{~h}$ of caffeine incubation were recorded, as sperm acrosomal reaction ability.

\section{Sperm morphology}

Determination of sperm morphology was performed by Diff-Quik rapid staining technique (Natali et al. 2013). A drop $(10 \mu \mathrm{L})$ of the sperm suspension was spread over the surface of the glass slide. The air-dried slide was fixed in $95 \%$ methyl alcohol for an hour and then stained by serially immersed in solution 1 (eosinophilic) for $10 \mathrm{~s}$ and solution 2 (basophilic) for 5 s. Eventually, the slides were rinsed in running water to get rid of the excess stain. The stained slides were read under a brightfield microscope at 1,000 magnification with oil immersion (Helmet Hund $\mathrm{GmbH}$, WetzlarNauborn, Germany). A total of 200 sperm for each slide were examined for the appearance of normal and abnormal morphology, e.g., sperm with head, midpiece, and tail defects. However, only the percentage of morphologically normal sperm was reported in the results.

\section{Statistical analysis}

A Shapiro-Wilk test in PASW Statistics 18 (SPSS Inc., Chicago, IL, USA) was used to test for normal distribution of data. Normally distributed data were analyzed using Independent-Samples T-Test to determine the level of significance between the control $\left(\mathrm{CaCO}_{3}\right)$ and experimental (chicken BEP) groups. Values of $\mathrm{P}<0.05$ were considered statistically significant. Results are expressed as means \pm standard deviation (SD).

\section{RESULTS AND DISCUSSION}

\section{Results}

The mean body weights of rats in the control and experimental groups increased progressively throughout eight weeks of the study (Figure 1). Additionally, at the end of week $8^{\text {th }}$, the net body weight gains measured in both groups were comparable. There was no significant difference $(\mathrm{P}>0.05)$ between them, as shown in Figure 2.

Results of epididymal sperm analysis of the rats from both groups are summarized in Figure 3. The sperm quantity (concentration) and quality (the motility, viability, resistance to hypotonic stress, acrosomal reaction ability, and morphology) of rats in the experimental group were not significantly different $(\mathrm{P}>$ 0.05) from those in the control. Irrespective of group, the representative microphotographs of sperm morphology are illustrated in Figure 4.

\section{Discussion}

This present study examined the effect of chicken BEP as a calcium source in rodent diet on the sperm quality of male Wistar rats. Results obtained, with our expectation, will be used as fundamental data extrapolated to humans. Calcium is a significant element that acts as an intracellular second messenger. It is crucial for sperm to maintain the normal functions including spermatogenesis, sperm motility, capacitation, acrosome reaction, chemotaxis, and fertilization (Valsa et al. 2015). Reduced seminal 


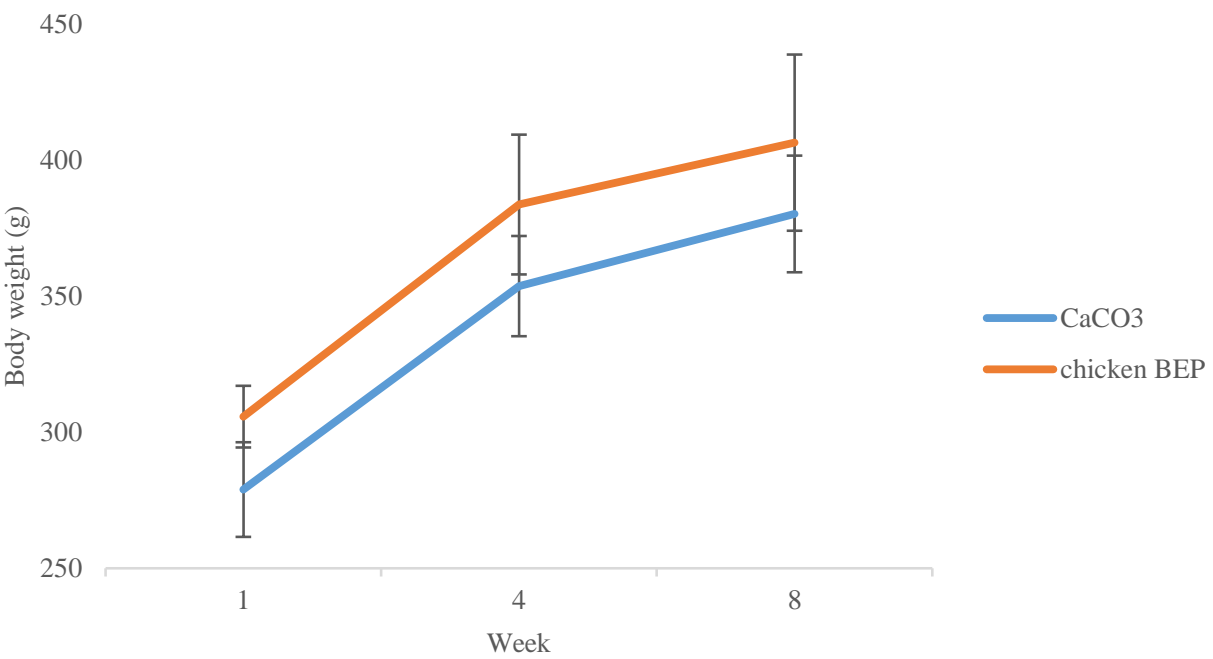

Figure 1. Mean body weight for the period of treatment in male Wistar rats. Values represented are means \pm SD.
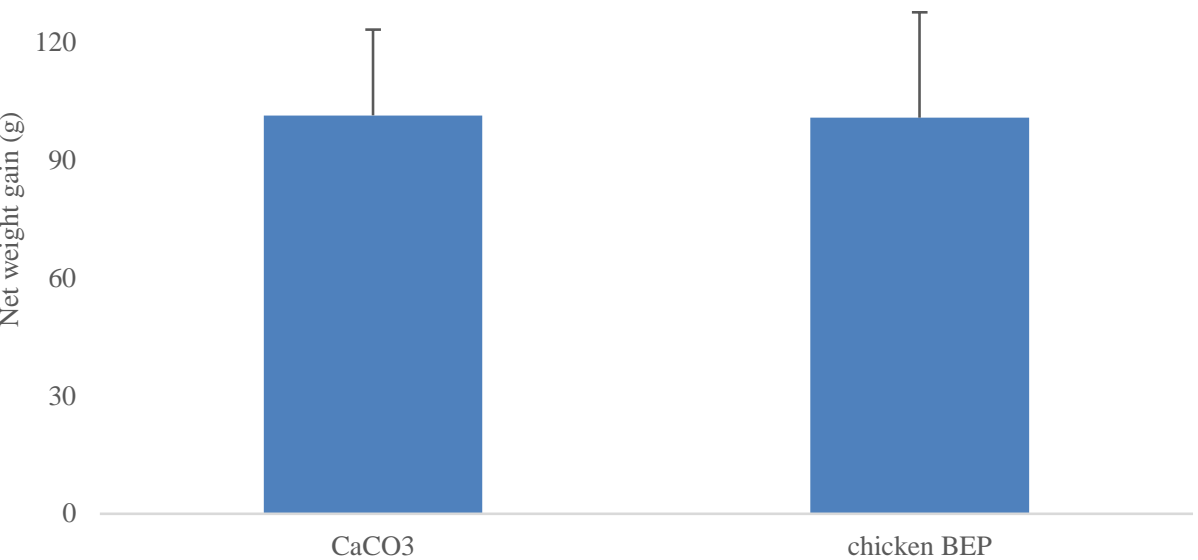

chicken BEP

Figure 2. Rats' net weight gain after eight weeks of treatment. Values are represented as means $\pm \mathrm{SD}$. P > 0.05 compared to the control $\left(\mathrm{CaCO}_{3}\right)$.

calcium concentrations were positively correlated with decreased sperm motility and membrane integrity and reduced sperm counts (Talluri et al. 2017). In the present study, male rats were given chicken BEP for eight weeks. This period lasts longer than the duration of spermatogenesis in Wistar rats, i.e., approximately 52-53 days (Clouthier et al. 1996). Therefore, in case of having a positive or negative influence on the reproductive system, there should be some alterations in the sperm quality of rats in the experimental group. However, it was found that epididymal sperm characteristics of rats given chicken BEP were not significantly different from, and even tended to be better than, those in the control Furthermore, throughout the entire study period, rats in the experimental group exhibited normal behavior; they still ate and normally moved (data not shown). Their body weights increased continuously and at the end of the study, net body weight gains of rats in the experimental group were similar to the control. Bodyweight changes suggest that chicken BEP when added into foods, does not decrease the acceptability and palatability of such diets. This suggestion was supported by previous studies undertaken in animals (Atmokotomo et al. 2013) and human subjects (Kettawan et al. 2002; Sittikulwitit et al. 2004).

Moreover, our findings on the unaltered sperm quality imply that the in vivo bioavailability of calcium from chicken BEP was not inferior to that from $\mathrm{CaCO}_{3}$, a commercial calcium salt. The high calcium bioavailability of chicken BEP has also been reported in 
(a)

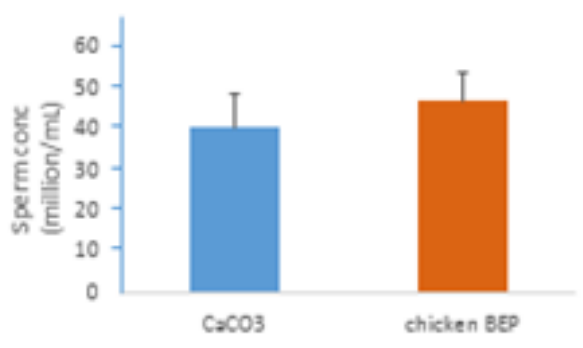

(c)

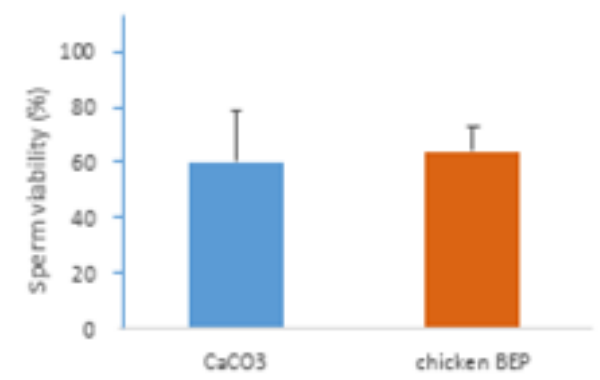

(e)

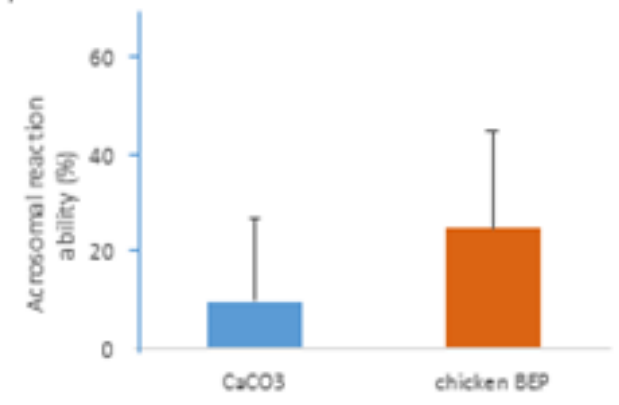

(b)

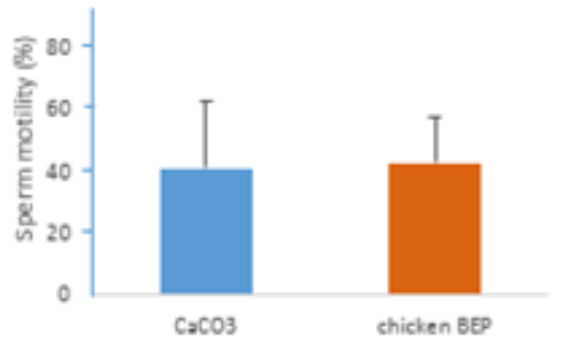

(d)

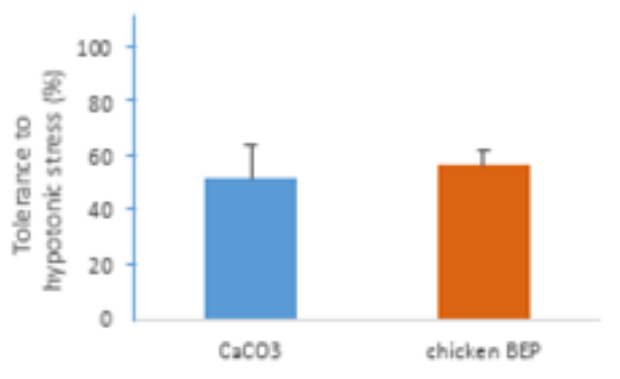

(f)

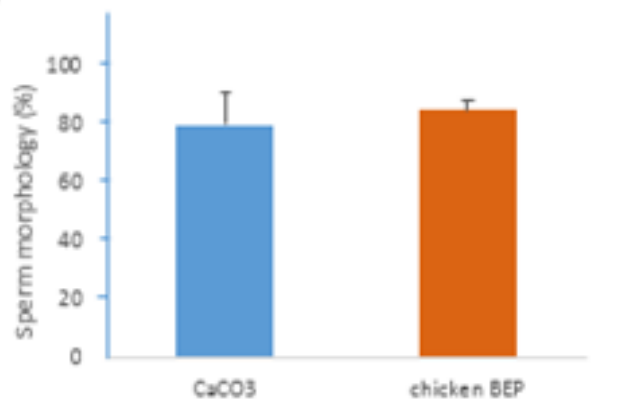

Figure 3. Effect of chicken BEP on epididymal sperm characteristics. (a) Sperm concentration, (b) sperm motility, (c) sperm viability, (d) sperm tolerance to hypotonic stress, (e) acrosomal reaction ability of sperm, and (f) sperm morphology. Values are represented as means \pm $\mathrm{SD}$ following eight weeks of treatment. All parameters are $\mathrm{P}>0.05$ compared to the control $\left(\mathrm{CaCO}_{3}\right)$.
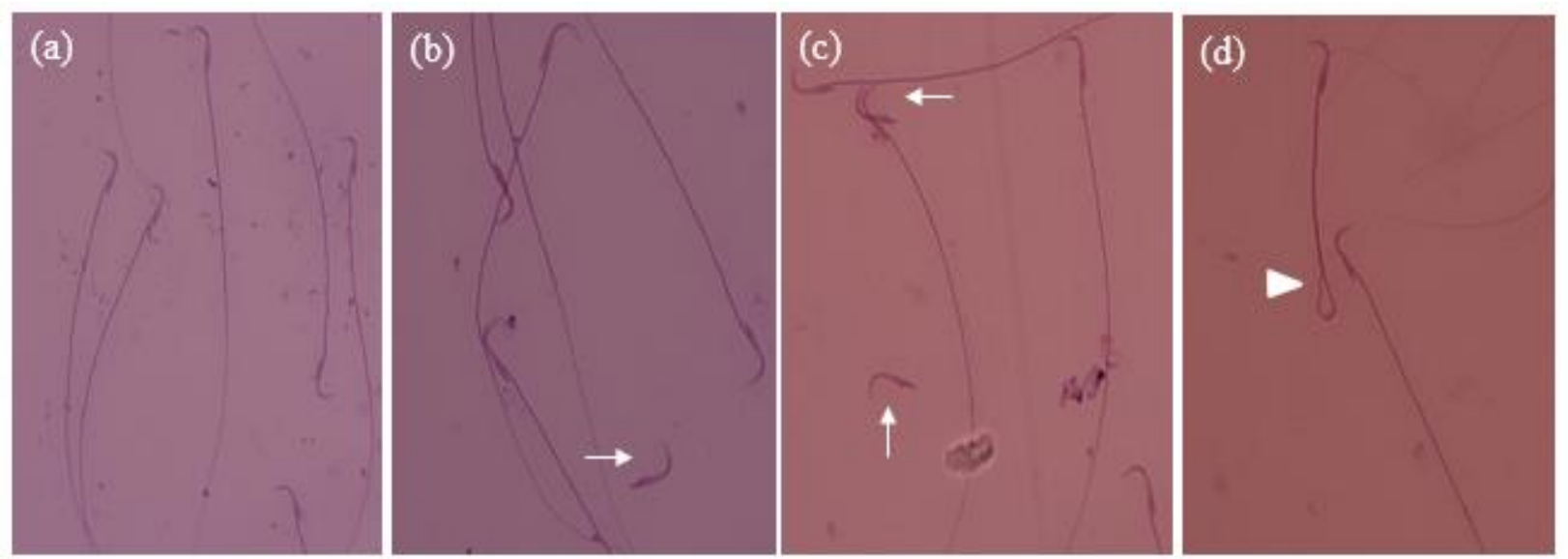

Figure 4. Sperm morphology of Wistar rats using Diff-Quik staining (1000 $\times$ ). Sperm with normal (a) and abnormal morphologies (b)-(d). (b) and (c) detached heads (arrows); (d) bent tail (an arrowhead) 
female rats. In that study, chicken BEP suspension was given to pregnant Sprague Dawley rats from the first day of pregnancy to the second week of parturition.

The calcium level of rat pups' teeth in the chicken BEP supplementation group was significantly higher than the control (Atmokotomo et al. 2019). The higher calcium bioavailability of chicken BEP, when compared with the same calcium content in traditional calcium-rich diet sources and some forms of commercial calcium salts was explained by the fact that chicken BEP does not contain substances such as fiber, phytate, and oxalate which can bind to calcium becoming insoluble complexing agents and consequently can interfere with the absorption of calcium in the gut (Whisner et al. 2014). Moreover, another explanation is that chicken BEP contains calcium and phosphorus in the appropriate ratio of $2: 1$, which enhances calcium absorption and retention in the body (Kettawan et al. 2002; Loughrill et al. 2017).

Chicken BEP utilized in the present study is deemed safe for consumption because, using this preparation technique, heavy metal levels, and microorganism and moisture contents in the product were very low. Lead and cadmium were non-detectable; total plate count was less than $10 \mathrm{CFU} / \mathrm{g}$, and water activity (Aw) was just 0.152 . A very low Aw can delay microbial growth and food spoilage (Kettawan et al. 2002). Besides the above reasons, chicken BEP is suitable for consumption by humans in every culture unlike pork or cow by-products forbidden for Muslims and some Indians, for example, due to religious restrictions, their belief, and their laws (Brondz 2018; Kennedy et al. 2018).

\section{CONCLUSION}

Chicken BEP addition into rodent diet had no adverse effect on the quantity and quality of epididymal sperm in male Wistar rats. This initially suggests chicken BEP being an alternative natural calcium source that is effective and not expensive. However, before stepping up to clinical trials in human participants, the chronic effect of chicken BEP intake on the reproductive and other body systems should be determined. Also, the in vitro and in vivo fertility of sperm from chicken BEP consumers require further study.

\section{ACKNOWLEDGMENT}

The authors are grateful to Ms. Kornkanok Promthep for providing a Diff-Quik staining set and Ms. Patporn Chankong for assisting with the acrosomal status evaluation by fluorescence microscopy. This research was financially supported in part by Thailand Science Research and Innovation (RDG 6050013).

\section{REFERENCES}

Asadi MH, Zafari F, Sarveazad A, Abbasi M, Safa M, Koruji M, Yari A, Alizadeh Miran R. 2014. Saffron improves epididymal sperm parameters in rats exposed to cadmium. Nephrourol Mon. 6:e12125. DOI: 10.5812/numonthly. 12521 .

Atmokotomo P, Arlan A, Sitosari H, Haniastuti T, Linggar Jonarta A. 2019. The Effect of Chicken Bone Powder Supplementation during Pregnancy and Lactation on the Calcium Level of Rat Pups' Teeth. KnE Life Sci. 4:76. DOI: $10.18502 / \mathrm{kls.v4i11.3854.}$

Atmokotomo P, Arlan A, Sitosari H, Saputri T, Wardani I. 2013. Utilization of chicken bone extract powder (beta) the rest of the chicken restaurant business as a feed supplement pellet wistar mice to optimize teething gear growth. In: Lap Akhir Penelit PKM-P. p. 8-9.

Badkoobeh P, Parivar K, Kalantar SM, Hosseini SD, Salabat A. 2013. Effect of nano-zinc oxide on doxorubicininduced oxidative stress and sperm disorders in adult male Wistar rats. Iran J Reprod Med. 11:355-64.

Brondz I. 2018. Why Judaism and Islam Prohibit Eating Pork and Consuming Blood as a Food? Voice Publ. 04:22-31. DOI: $10.4236 / v p .2018 .42003$.

Buranaamnuay K. 2019. Comparison of different methods for sperm vitality assessment in frozen-thawed Holstein bull semen. Thai J Vet Med. 49:249-255.

Buranaamnuay K. 2020. Effect of Different Permeable Cryoprotectants on the Quality of Cat Epididymal Spermatozoa. Cryo Letters. 41:237-244.

Cashman KD, Flynn A. 1996. Effect of dietary calcium intake and meal calcium content on calcium absorption in the rat. Br J Nutr. 76:463-470. DOI: 10.1079/BJN19960051.

Chung J-J, Navarro B, Krapivinsky G, Krapivinsky L, Clapham DE. 2011. A novel gene required for male fertility and functional CATSPER channel formation in spermatozoa. Nat Commun. 2:153. DOI: $10.1038 /$ ncomms 1153

Clouthier DE, Avarbock MR, Maika SD, Hammer RE, Brinster RL. 1996. Rat spermatogenesis in mouse testis. Nature. 381:418-421. DOI: 10.1038/381418a0.

Funahashi H, Nagai T. 2001. Regulation of in vitro penetration of frozen-thawed boar spermatozoa by caffeine and adenosine. Mol Reprod Dev. 58:424-431. DOI: 10.1002/1098-2795(20010401)58:4<424::AIDMRD10>3.0.CO;2-1.

Harchegani $\mathrm{AB}$, Irandoost $\mathrm{A}$, Mirnamniha $\mathrm{M}$, Rahmani $\mathrm{H}$, Tahmasbpour E, Shahriary A. 2019. Possible mechanisms for the effects of calcium deficiency on male infertility. Int $\mathrm{J}$ Fertil Steril. 12:267-272. DOI: 10.22074/ijfs.2019.5420

Iswadi MI, Ann ZF, Hafiz MM, Hafiz MD, Fahrul FJ, Hajarian H, Wahid H, Zawawi I, Khairiah MS, Mazni OA. 2012. Collection, analysis and cryopreservation of semen from Malayan gaur (Bos gaurus hubbacki): A preliminary study. Open Vet J. 2:109-14. 
Jaffar FHF, Osman K, Hui CK, Zulkefli AF, Ibrahim SF. 2021. Edible bird's nest supplementation improves male reproductive parameters of Sprague Dawley rat. Front Pharmacol. 12:631402. DOI: 10.3389/fphar.2021.631402.

Kennedy U, Sharma A, Phillips C. 2018. The sheltering of unwanted cattle, experiences in India and implications for cattle industries elsewhere. Animals. 8:64. DOI: 10.3390/ani8050064.

Kettawan A, Sungpuag P, Chavasit V, Sirichakwal P. 2002. Chicken bone calcium extraction and its application as a food fortificant. J Natl Res Counc Thail. 34:163-180.

Loughrill E, Wray D, Christides T, Zand N. 2017. Calcium to phosphorus ratio, essential elements and vitamin D content of infant foods in the UK: Possible implications for bone health. Matern Child Nutr. 13:e12368. DOi: $10.1111 / \mathrm{mcn} .12368$.

Natali I, Muratori M, Sarli V, Vannuccini M, Cipriani S, Niccoli L, Giachini C. 2013. Scoring human sperm morphology using Testsimplets and Diff-Quik slides. Fertil Steril. 99:1227-1232.e2. DOI: 10.1016/j.fertnstert.2012.11.047.

Omirinde JO, Olukole SG, Oke BO. 2019. Age-related changes in the testicular and epididymal sperm parameters in the African Greater Cane rat (Thryonomys swinderianus, Temminck, 1827). Anim Res Int. 1:3255-3264.
Sittikulwitit S, Sirichakwal PP, Puwastien P, Chavasit V, Sungpuag P. 2004. In vitro bioavailability of calcium from chicken bone extract powder and its fortified products. J Food Compos Anal. 17:321-329. DOI: 10.1016/j.jfca.2004.03.023.

Stewart TA, Davis FM. 2019. An element for development: Calcium signaling in mammalian reproduction and development. Biochim Biophys Acta - Mol Cell Res. 1866:1230-1238. DOI: 10.1016/j.bbamcr.2019.02.016.

Talluri TR, Mal G, Ravi SK. 2017. Biochemical components of seminal plasma and their correlation to the fresh seminal characteristics in Marwari stallions and Poitou jacks. Vet World. 10:214-220. DOI: 10.14202/vetworld.2017.214-220.

Valsa J, Skandhan KP, Khan PS, Avni KPS, Amith S, Gondalia M. 2015. Calcium and magnesium in male reproductive system and in its secretion. I. level in normal human semen, seminal plasma and spermatozoa. Urol J. 82:174178. DOI: 10.5301/urologia.5000039.

Veldurthy V, Wei R, Oz L, Dhawan P, Jeon YH, Christakos S. 2016. Vitamin D, calcium homeostasis and aging. Bone Res. 4:16041. DOI: 10.1038/boneres.2016.41.

Whisner CM, Martin BR, Nakatsu CH, McCabe GP, McCabe LD, Peacock M, Weaver CM. 2014. Soluble maize fibre affects short-term calcium absorption in adolescent boys and girls: a randomised controlled trial using dual stable isotopic tracers. $\mathrm{Br} \mathrm{J}$ Nutr. 112:446-456. DOI: 10.1017/S0007114514000981. 